\title{
The Impact of Settlement Pattern of Some Nigerian Cities on the Spread of Covid-19 Pandemic
}

\author{
Ukpali E. Obongha and Leonard Edadi Ukam
}

\section{ABSTRACT}

The pattern of settlements in some Nigerian towns/cities have posed serious concerns to Epidemiologists, Virologists, and Planners in modern times. The rate at which buildings are erected close to one another without maintaining standards is alarming and requires professional attention. The aim of this study is to establish the linkage between the settlement pattern of some Nigerian cities and the spread of Coronavirus (covid-19) with a view to drawing the attention of relevant stakeholders (Government, Ministries of Urban Development, and Town Planners) to look inward towards revitalizing and improving on the settlements, in order to reduce subsequent spread in events of similar outbreaks. The study adopted survey method with the instrumentality of questionnaire administration in interviewing 110 people across 11 States of the federation. Findings reveals that most of these settlements were illegally erected and are characterized by congestion and lack of facilities (toilets, kitchens, bathrooms, and running water) while the available few are shared. These characteristics have made social distancing and regular washing of hands as measures to reduce the spread of covid-19 difficult to be achieved. The study, however, recommends an incremental approach of urban redevelopment, spot clearance, and rehabilitation of the identified settlements, in order to reduce the spread of diseases in the nearest future

Keywords: Covid-19, Face me I Face You, Settlement Pattern, Shared Apartment and Facilities, Social Distancing.

\section{INTRODUCTION}

Settlements worldwide are located on the earth's surface with people living in them. Each settlement has a site and location, site refers to the land on which settlement is built for example, Gulfport, Mississippi is sited on the marshy area of the Gulf coast which borders the Gulf of Mexico. While, location refers to the position of settlement in relation to other places in the region [2]. For example, Egypt is located on the focal point of the River Nile. Settlements are known to change spatially with time, but the pattern of such change varies according to certain factors such as transportation and socio-economic activities; political fragmentation; population density; infrastructural distribution and social amenities; economic development; industrialization and urbanization; social networks; topographical conditions; religious and cultural factors [7].

In Nigeria for example, towns/cities have common features of a dual urban pattern (the traditional and colonial towns). The traditional/walled towns existed in Nigeria before the arrival of the British colonial masters, characterized by religion dominated and socio-cultural uniqueness [3]. These characteristics of the traditional/walled Nigerian towns/cities played a dominant role in her pattern of settlements specifically, built with locally sourced building materials such as mud, thatch, wood, stone, etc. and possessed a unique pattern from the first settlers [1]. These traditional/walled settlements are presently, existing in most of the ancient towns/cities of Nigeria and are known to encourage compact form of arrangement with settlements built round containing dwellings of multiple apartments that accommodates tenants and the extended family members.

Nigeria's pattern of settlement is characteristically different from the planned developed cities of the world. Most cities in Nigeria were developed before planning and have been compact areas with high population densities [8]. They contain buildings built close to one another, some of which without appropriate setbacks, height and coverage and as such defying social distancing in events of outbreak of pandemics such as covid-19 and severe acute respiratory syndrome (SARS).

Coronavirus disease (covid-19) is an infectious disease caused by novel coronavirus which emanated from Wuhan, a town in the Peoples Republic of China in December, 2019 [9]. Covid-19 was named after the year 2019 as the base- 
year that the disease was discovered. It affects the respiratory organs of humans by fast weakening the immune systems and antibodies that are meant to fight foreign substances (diseases) in the human system. "Epidemiology and virology studies suggest that transmission mainly occurs from symptomatic people to others by close contact through respiratory droplets, by direct contact with infected persons, or by contact with contaminated surfaces/objects". There is also growing evidence of airborne transmission [9]. "The clinical presentation of Severe Acute Respiratory Syndrome Coronavirus disease (SARS-CoV-2, causative virus) resembles viral pneumonia" [9].

Virology and clinical studies that have collected repeated biological samples from confirmed patients demonstrate the shedding of SARS-CoV-2 is highest in upper respiratory tract (URT), (i.e. nose and throat), early in the course of the infection within the first three days of the symptomatic appearance. The symptoms to positive Ribonucleic Acid (RNA) virus include cough, runny nose, breathing difficulty, fever, headache, sore throat, chills, abdominal pain, body pain, sudden loss of taste and smell, fatigue, and high temperature within fourteen days' post infection. Covid-19 pandemic attributes to over 600,000 deaths, 12 million infected cases all over the world including Nigeria as at July, 2020 [9].

The virus came into Nigeria on February 27, 2020 through infected persons from high risk countries who used the Lagos and Abuja international air ports. The spread was faster in Lagos, Abuja, Ogun, Edo, Kano, Kaduna, Oyo, Katsina, Yobe, Jigawa, and Plateau States [5]. However, with the fast spread of covid-19 in Nigeria, Planners, Epidemiologists, and Virologists began to inquest about the pattern of settlements in the affected cities. This study concentrates on the settlement pattern of covid-19 highly affected states, within its congested/compact settlements locally known as shanty/squatter, ghetto, face me I face you, and bacha where facilities such as kitchens, bathrooms, and toilets are grossly inadequate and the available few are shared. Living conditions violates social distancing due to congestion, grubby environment lacking hygiene and water supply.

The aim of this study is to establish the linkage between the settlement pattern of some Nigerian cities and the spread of covid-19 with a view to drawing the attention of relevant stakeholders (Government, Ministries of Urban Development, and Town Planners) to look inward towards revitalizing and improving on the settlements, in order to reduce subsequent spread in events of similar outbreaks.

\section{MATERIALS AND METHOD}

The study is conducted in Nigeria located between longitude $3 \mathrm{oE}, 15 \mathrm{oE}$ and latitude $4 \mathrm{oN}, 14 \mathrm{oN}$. The study area has thirty-six States and Abuja the Federal Capital Territory (FCT). The study made use of primary and secondary data sources. The primary sources of data collection were collected through the administration of questionnaires for first-hand information as used in [7] to ascertain the impact of settlement pattern of some Nigerian cities on the spread of covid-19. The secondary data were sourced from the collection of journal articles, reports, documentaries, and text books on the subject matter.

Data on social distancing among the residents of the selected settlements, shared apartment and facilities such as rooms, toilets, bathrooms, kitchens, and running water. These types of data are required in the study because, conditions for prevention of the spread of coronavirus are by maintaining two metres social distancing amongst individuals, the use of nose mask, regular washing of hands with soap in a running water, use of alcohol basedsanitizers, avoiding crowded places, and maintaining high standard cleanliness and hygiene. All these conditions are defied in some of the settlement pattern of Nigerian cities particularly, those locally called face me I face you, bacha, shanty/squatter, ghetto.

A total of one hundred and ten (110) questionnaires were distributed to the 11 major covid-19 affected States in Nigeria (Lagos, Abuja, Ogun, Edo, Kano, Kaduna, Oyo, Katsina, Yobe, Jigawa, and Plateau). Two settlement locations were selected from each State based on the characteristics mentioned above. Ten questionnaires were sent to each State through social media online platforms and respondents filled and returned same. The analyses are conducted with the instrumentality of descriptive statistics using Tables and percentages while GIS mapping is also introduced for locational and positional attributes of these States. The Figure 1 shows the Map of Nigeria as the study area with 36 States and the FCT.

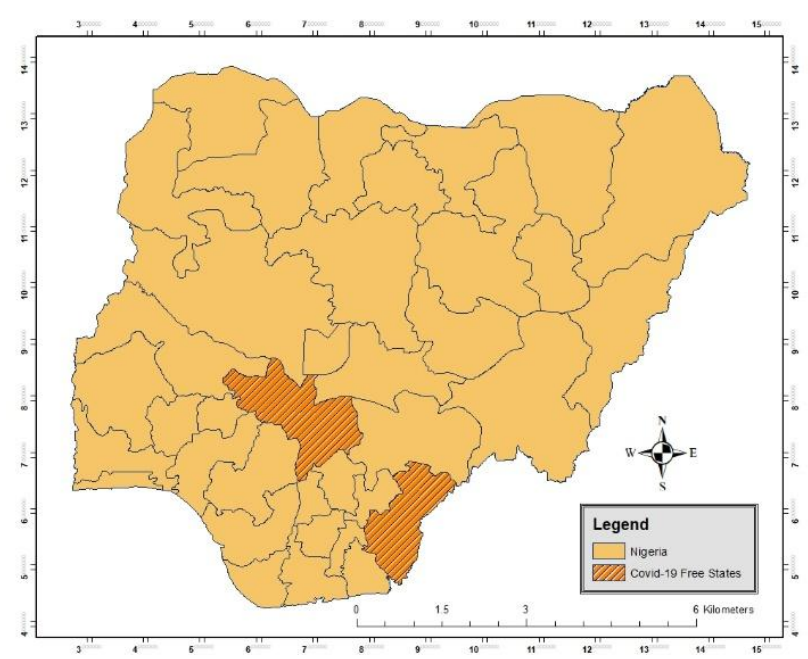

Fig. 1. Map of Nigeria showing 36 States and the FCT.

Figure 1: Map of Nigeria showing 36 States and the FCT indicating Cross River and Kogi States as the States that were free of Covid-19. The two States were confirmed free by NCDC after carrying out a test within a sample frame and all turned out negative. However, as movement of people continues without precautions, Kogi State thereafter, recorded cases of covid-19. Cross River State in July, 2020 also confirmed cases of covid-19 as revealed by the NCDC. 


\section{ANALYSIS AND DISCUSSION}

The data collected on social distancing/crowded settlements and lack of facilities such as running water, toilets, kitchens, and bathrooms and the shared available few are analyzed below using descriptive statistics.

TABLE 1A: SETTLEMENTS NOT MAINTAINING SOCIAL DISTANCING/CROWDED

\begin{tabular}{|c|c|c|}
\hline Lagos & Frequency & \% \\
\hline Bariga & 6 & 60 \\
\hline Makoko & 4 & 40 \\
\hline Total & $\mathbf{1 0}$ & $\mathbf{1 0 0}$ \\
\hline
\end{tabular}

Source: Researchers Field Survey, 2020.

Table 1a shows that the selected settlements in Lagos State are crowded and difficult to maintained social distancing. Plate 1 confirmed this finding.

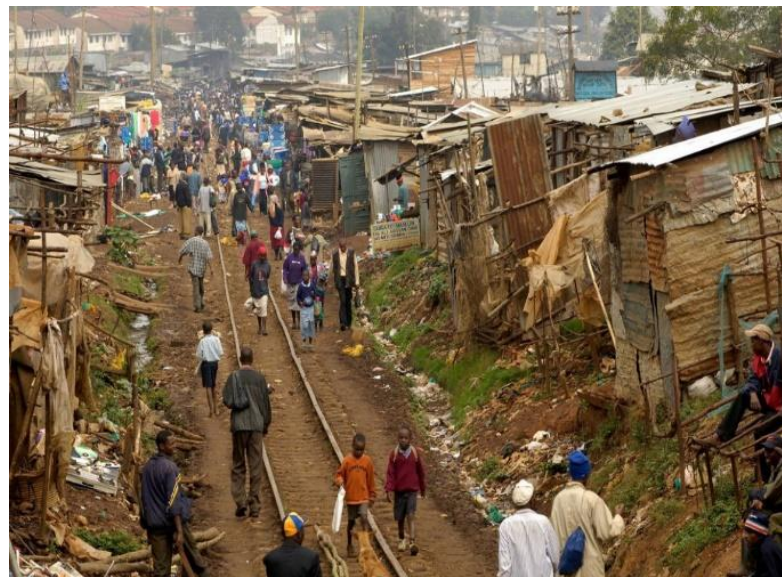

Plate 1. Source: Google Photo of Bariga, Lagos.

TABLE 1B: SETTLEMENTS NOT MAINTAINING SOCIAL DISTANCING/CROWDED

\begin{tabular}{|c|c|c|}
\hline Abuja & Frequency & $\mathbf{\%}$ \\
\hline Kugbo & 5 & 50 \\
\hline Nyanya & 5 & 50 \\
\hline Total & $\mathbf{1 0}$ & $\mathbf{1 0 0}$ \\
\hline
\end{tabular}

Source: Researchers Field Survey, 2020.

Table 1b shows that the selected settlements in FCT are crowded and have no idea of social distancing despite the guidelines issued by WHO and NCDC.

TABLE 1C: SeTtLemEnTS NOt MAINTAINING Social DISTANCING/CROWDED

\begin{tabular}{|c|c|c|}
\hline \multicolumn{3}{|c|}{ DISTANCING/CROWDED } \\
\hline Ogun & Frequency & $\mathbf{\%}$ \\
\hline Ajeromi & 4 & 40 \\
\hline Abeokut & 6 & 60 \\
\hline Total & $\mathbf{1 0}$ & $\mathbf{1 0 0}$ \\
\hline
\end{tabular}

Source: Researchers Field Survey, 2020.

Table 1c shows that congestion and crowdedness are common in Abeokuta due to its closeness to Lagos and this has made it impossible to maintain social distancing as prescribed by WHO to curb covid-19 spread.

TABLE 1D: SETTLEMENTS NOt MaINTAINING Social DISTANCING/CROWDED

\begin{tabular}{|c|c|c|}
\hline Kano & Frequency & \% \\
\hline Gwarzo & 3 & 30 \\
\hline Ancient Kano City & 7 & 70 \\
\hline Total & $\mathbf{1 0}$ & $\mathbf{1 0 0}$ \\
\hline
\end{tabular}

Source: Researchers Field Survey, 2020.
Table 1d shows Gwarzo and the Ancient city of Kano. These communities were in doubt with the existence of covid-19. This made them not to observe the guidelines issued by WHO. The Plate 2 shows the pattern of settlement in ancient Kano with congested and crowded buildings.

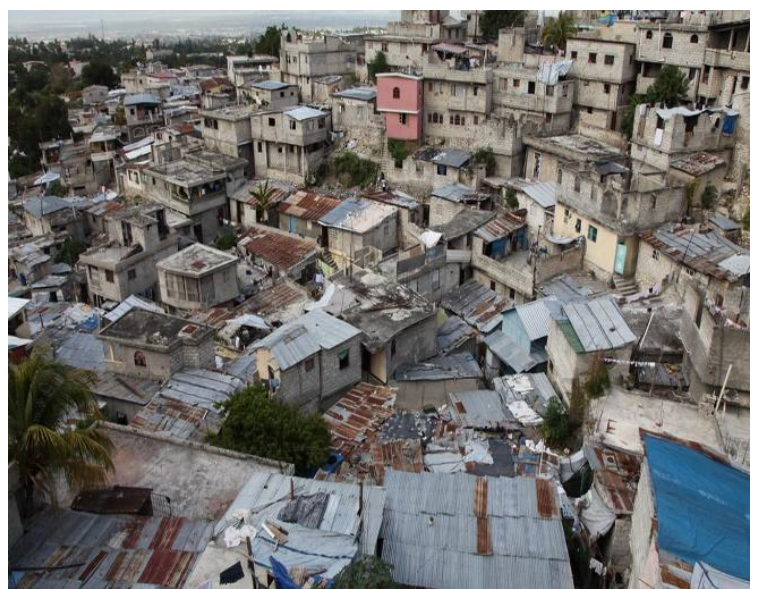

Plate 2. Source: Google Photo of Ancient Kano.

TABLE 1E: SETTLEMENTS NOT MAINTAINING Social DISTANCING/CROWDED

\begin{tabular}{|c|c|c|}
\hline Kaduna & Frequency & \% \\
\hline Gwari & 4 & 40 \\
\hline Kakuri & 6 & 60 \\
\hline Total & $\mathbf{1 0}$ & $\mathbf{1 0 0}$ \\
\hline
\end{tabular}

Source: Researchers Field Survey, 2020.

Table 1e above shows Gwari and Kakuri settlements of Kaduna State. Kakuri is the industrial region of Kaduna State which is highly congested and has become difficult to maintain social distancing as recommended by WHO to reduce the spread of covid-19. The Plate 3 shows this congestion.

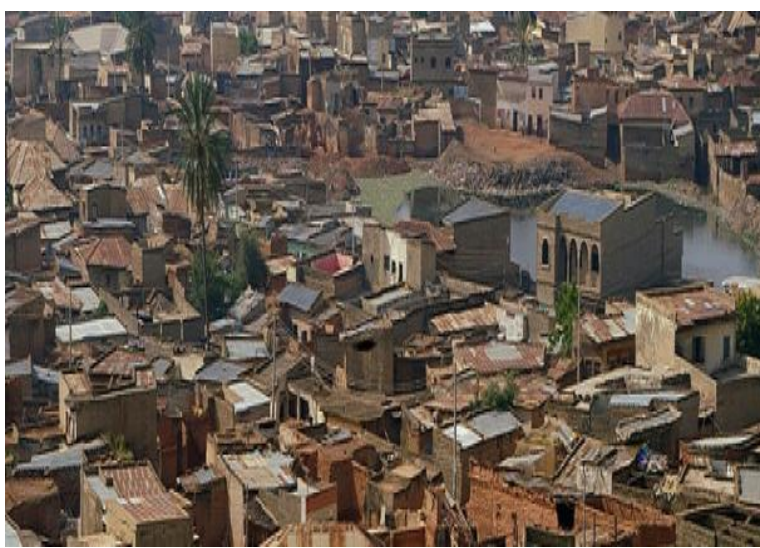

Plate 3. Source: Google Photo of Kakuri, Kaduna.

TABLE 1F: SETTLEMENTS NOT MAINTAINING SOCIAL DISTANCING/CROWDED

\begin{tabular}{|c|c|c|}
\hline Edo & Frequency & \% \\
\hline Benin Inner City & 3 & 30 \\
\hline Sabongida-Ora & 7 & 70 \\
\hline Total & $\mathbf{1 0}$ & $\mathbf{1 0 0}$ \\
\hline
\end{tabular}

Source: Researchers Field survey, 2020.

The ancient Benin City and Sabongida-Ora are areas of congestion with compact settlements and high population density. This condition is likely to defy social distancing among the residents. 
TABLE 1G: SETTLEMENTS NOT MAINTAINING SociAL DISTANCING/CROWDED

\begin{tabular}{|c|c|c|}
\hline Katsina & Frequency & \% \\
\hline Batagarawa & 6 & 60 \\
\hline Katsina Central & 4 & 40 \\
\hline Total & $\mathbf{1 0}$ & $\mathbf{1 0 0}$ \\
\hline
\end{tabular}

Source: Researchers Field Survey, 2020.

Table 1g: shows congested settlements of Katsina that resists social distancing. The people are crowded in these areas and can easily spread covid-19 if infected persons are in their midst.

TABLE 1H: SETTLEMENTS NOT MAINTAINING SOCIAL DISTANCING/CROWDED

\begin{tabular}{|c|c|c|}
\hline Oyo & Frequency & \% \\
\hline Bere & 5 & 50 \\
\hline Oyo Town & 5 & 50 \\
\hline Total & $\mathbf{1 0}$ & $\mathbf{1 0 0}$ \\
\hline
\end{tabular}

Source: Researchers Field Survey, 2020.

Bere and Oyo settlements have elements of crowdedness. Bere for example, contain some ghettos that the inhabitants easily forget about the WHO's guidelines for preventing covid-19.

TABLE 1I: SETTLEMENTS NOT MAINTAINING SOCIAL DISTANCING/CROWDED

\begin{tabular}{|c|c|c|}
\hline Yobe & Frequency & \% \\
\hline Damaturu & 5 & 50 \\
\hline Potiskum & 5 & 50 \\
\hline Total & $\mathbf{1 0}$ & $\mathbf{1 0 0}$ \\
\hline
\end{tabular}

Source: Researchers Field Survey, 2020.

Table 1i: shows Damaturu and Potiskum, these are towns but with spots were compact settlements are found. Majority of the inhabitants according to some respondents are ignorant about covid-19 and have no reason to maintain social distancing.

TABLE 1J: SETTLEMENTS NOT MAINTAINING SOCIAL DISTANCING/CROWDED

\begin{tabular}{|c|c|c|}
\hline Jigawa & Frequency & \% \\
\hline Dutse & 2 & 20 \\
\hline Gagarawa & 8 & 80 \\
\hline Total & $\mathbf{1 0}$ & $\mathbf{1 0 0}$ \\
\hline
\end{tabular}

Source: Researchers Field Survey, 2020.

Table 1j, shows Dutse and Gagarawa. The data shows that the Gagarawa settlement are crowded and defy social distancing. The Plate 4 is an indication that the dwellers are not aware of the need for keeping social distance.

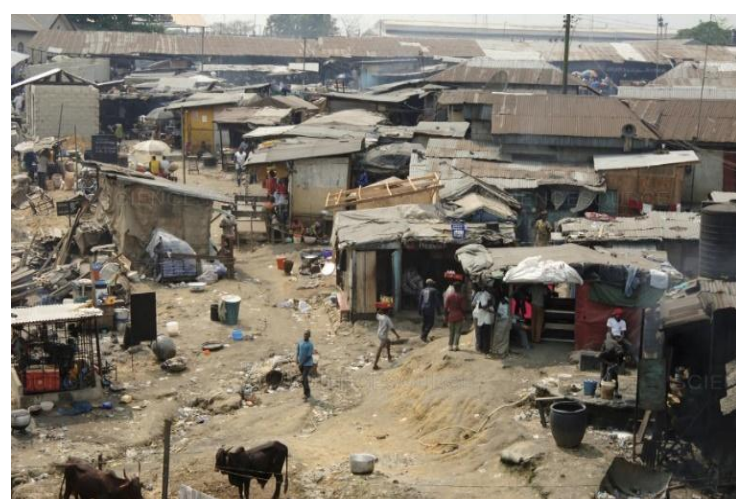

Plate 4. Source: Google Photo of Gagarawa, Jigawa.
TABLE 1K: SETTLEMENTS NOT MAINTAINING SOCIAL DISTANCING/CROWDED

\begin{tabular}{|c|c|c|}
\hline Plateau & Frequency & \% \\
\hline Gada Biu & 6 & 60 \\
\hline Agwan Rukuba & 4 & 40 \\
\hline Total & $\mathbf{1 0}$ & $\mathbf{1 0 0}$ \\
\hline
\end{tabular}

Source: Researchers Field Survey, 2020.

Table 1k show settlements of Gada Biu and Agwan Rukuba which are also compacted and have not obeyed the social distancing guideline. The Fig. 2 is the Map of Nigeria showing 11 States that are mostly affected with covid-19.

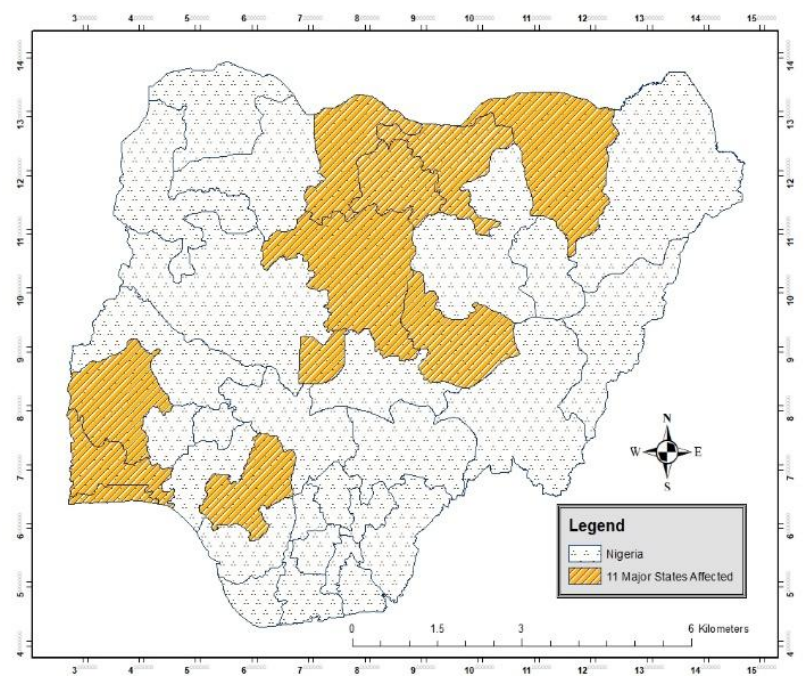

Fig. 2. Map of Nigeria showing 11 major States affected with COVID19.

The States are Lagos, FCT, Ogun, Kano, Kaduna, Edo, Katsina, Oyo, Yobe, Jigawa, and Plateau

TABLE 2A: SETTLEMENTS WITH SHARED FACILITIES (KITCHEN, BATHS/TOILETS, WATER) AND APARTMENTS

\begin{tabular}{|c|c|c|}
\hline Lagos & Frequency & $\%$ \\
\hline Bariga & 10 & 100 \\
\hline Makoko & $\begin{array}{l}\text { No facilities buts } \\
\text { hared apartments }\end{array}$ & \\
\hline Total & $\mathbf{1 0}$ & $\mathbf{1 0 0}$ \\
\hline
\end{tabular}

Source: Researchers Field Survey, 2020

These are settlements in Lagos State where facilities and apartments are either shared or not available for use. The shared facilities are likely to contain contaminated surfaces from respiratory droplets of infected persons and easily spread to others using same facilities.

TABLE 2B: SETTLEMENTS WITH SHARED FACILITIES (KITCHEN, BATHS/TOILETS, WATER) AND APARTMENTS

\begin{tabular}{|c|c|c|}
\hline Abuja & Frequency & \% \\
\hline Kugbo & 5 & 50 \\
\hline Nyanya & 5 & 50 \\
\hline Total & $\mathbf{1 0}$ & $\mathbf{1 0 0}$ \\
\hline
\end{tabular}

Source: Researchers Field Survey, 2020.

Table $2 \mathrm{~b}$ shows that the settlements of Kugbo and Nyanya in Abuja have most of their facilities shared which might easily result in contaminating surfaces with the novel virus. 
TABLE 2C: SETTLEMENTS WITH SHARED FACILITIES (KITCHEN, BATHS/TOILETS, WATER) AND APARTMENTS

\begin{tabular}{|c|c|c|}
\hline Ogun & Frequency & \% \\
\hline Ajeromi & 6 & 60 \\
\hline Abeokuta & 4 & 40 \\
\hline Total & $\mathbf{1 0}$ & $\mathbf{1 0 0}$ \\
\hline
\end{tabular}

Source: Researchers Field Survey, 2020.

Table 2c shows that Ajeromi and Abeokuta settlements shared facilities (toilets, kitchens, and bathrooms) and room apartments. Covid-19 could easily be spread among the residents living in these settlements. Some of the buildings contain corridors which separate the rooms and cooking is sometimes carried out along these corridors where every occupant of the building passes through.

TABLE 2D: SETTLEMENTS WITH SHARED FACILITIES (KITCHEN, BATHS/TOILETS, WATER) AND APARTMENTS

\begin{tabular}{|c|c|c|}
\hline Kano & Frequency & \% \\
\hline Gwarzo & 8 & 80 \\
\hline Ancient Kano City & 2 & 20 \\
\hline Total & $\mathbf{1 0}$ & $\mathbf{1 0 0}$ \\
\hline
\end{tabular}

Source: Researchers Field Survey, 2020.

Plate 2 is an indication that the inhabitants of these settlements (Table 2d) enjoys living together, sharing rooms and facilities. This is likely to induce the spread of covid-19.

TABLE 2E: SETTLEMENTS WITH SHARED FACILITIES (KITCHEN, BATHS/TOILETS, WATER) AND APARTMENTS

\begin{tabular}{|c|c|c|}
\hline Kaduna & Frequency & \% \\
\hline Gwari & 4 & 40 \\
\hline Kakuri & 5 & 60 \\
\hline Total & $\mathbf{1 0}$ & $\mathbf{1 0 0}$ \\
\hline
\end{tabular}

Source: Researchers Field Survey, 2020.

From Plate 3, the industrial area of Kakuri in Kaduna, contained multiple apartments with a high population made of large families and extended family members sharing room apartments and facilities. This type of condition exposes the settlers to danger such as the spread of covid-19.

TABLE 2F: SETTLEMENTS WITH SHARED FACILITIES (KITCHEN, BATHS/TOILETS, WATER) AND APARTMENTS

\begin{tabular}{|c|c|c|}
\hline Edo & Frequency & \% \\
\hline Benin Inner City & 3 & 30 \\
\hline Sabongida-Ora & 7 & 70 \\
\hline Total & $\mathbf{1 0}$ & $\mathbf{1 0 0}$ \\
\hline
\end{tabular}

Source: Researchers Field Survey, 2020.

Table $2 \mathrm{f}$ is made up of Ancient Benin City and Sabongida-Ore which are settlements made up of crowded buildings. Facilities and apartment such as rooms are shared which is risky in managing covid-19.

TABLE 2G: SETTLEMENTS WITH SHARED FACILITIES (KITCHEN, BATHS/TOILETS, WATER) AND APARTMENTS

\begin{tabular}{|c|c|c|}
\hline Katsina & Frequency & \% \\
\hline Batagarawa & 6 & 60 \\
\hline Katsina Central & 4 & 40 \\
\hline Total & $\mathbf{1 0}$ & $\mathbf{1 0 0}$ \\
\hline
\end{tabular}

Source: Researchers Field Survey, 2020.

Table $2 \mathrm{~g}$ contains settlements of Batagarawa and the inner city of Katsina. Batagarawa is made up of few people with formal education and they enjoy living in groups. These groups in turn result to crowded and congested accommodation with shared facilities.

TABLE 2G: SETTLEMENTS WITH SHARED FACILITIES (KITCHEN, BATHS/TOILETS, WATER) AND APARTMENTS

\begin{tabular}{|c|c|c|}
\hline Oyo & Frequency & $\%$ \\
\hline Bere & 7 & 70 \\
\hline Oyo Town & 3 & 30 \\
\hline Total & $\mathbf{1 0}$ & $\mathbf{1 0 0}$ \\
\hline
\end{tabular}

Source: Researchers Field Survey, 2020.

Table $2 \mathrm{~h}$ shows settlements with shared facilities in Oyo town and Bere. The survey show that Bere have shared facilities which is highly risky considering the nature of covid-19.

TABLE 2I: SETTLEMENTS WITH SHARED FACILITIES (KITCHEN, BATHS/TOILETS, WATER) AND APARTMENTS

\begin{tabular}{|c|c|c|}
\hline Yobe & Frequency & \% \\
\hline Damaturu & 5 & 50 \\
\hline Potiskum & 5 & 50 \\
\hline Total & $\mathbf{1 0}$ & $\mathbf{1 0 0}$ \\
\hline
\end{tabular}

Source: Researchers Field Survey, 2020.

Most of the settlements in Damaturu and Potiskum have shared facilities (toilet, kitchen and baths) and rooms.

TABLE 2D: SETTLEMENTS WITH SHARED FACILITIES (KITCHEN, BATHS/TOILETS, WATER) AND APARTMENTS

\begin{tabular}{|c|c|c|}
\hline Jigawa & Frequency & $\%$ \\
\hline Dutse & 8 & 80 \\
\hline Gagarawa & 2 & 20 \\
\hline Total & $\mathbf{1 0}$ & $\mathbf{1 0 0}$ \\
\hline
\end{tabular}

Source: Researchers Field Survey, 2020.

From the Plate 4, it is obvious that Gagarawa settlement shared few of the available facilities.

TABLE 2K: SETTLEMENTS WITH SHARED FACILITIES (KITCHEN, BATHS/TOILETS, WATER) AND APARTMENTS

\begin{tabular}{|c|c|c|}
\hline Plateau & Frequency & $\%$ \\
\hline Gada Biu & 5 & 50 \\
\hline Agwan Rukuba & 5 & 50 \\
\hline Total & $\mathbf{1 0}$ & $\mathbf{1 0 0}$ \\
\hline
\end{tabular}

Source: Researchers Field Survey, 2020.

Table 2k shows Gada Biu and Agwan Rukuba in Plateau State shared toilets, kitchens and bathrooms and often shared room apartments with friends and relatives. This practice is unhealthy considering the pervasiveness of covid-19. Figure 3 shows the location and position of the most affected states with covid-19. 


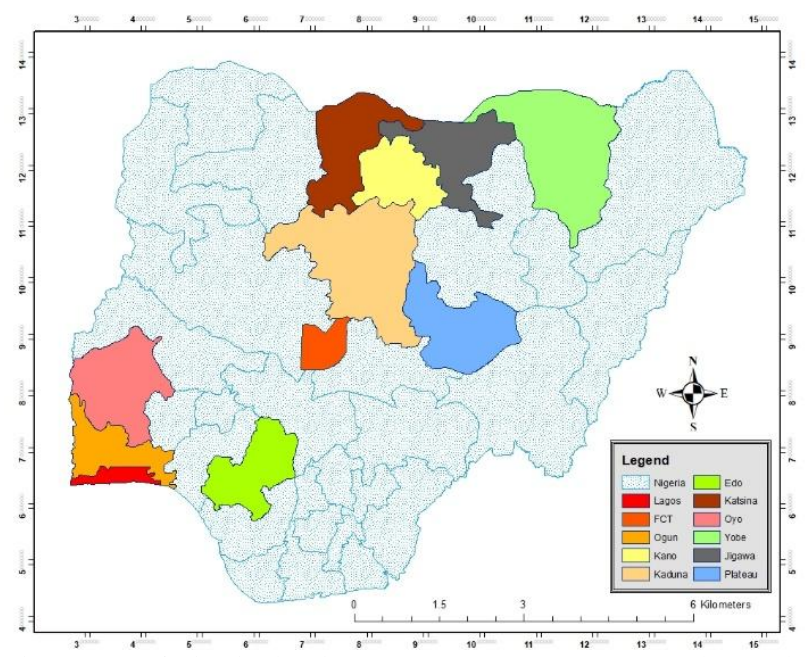

Fig. 3. Map of Nigeria showing Lagos, FCT, Ogun, Kano, Kaduna, Edo, Katsina, Oyo, Yobe, Jigawa, and Plateau States as most affected with covid-19.

\section{CONCLUSION}

In conclusion, this study is aimed of at establishing the linkage between the settlement pattern of some Nigerian cities and the spread of covid-19 with a view to drawing the attention of relevant stakeholders (Government, Ministries of Urban Development, and Town Planners) to look inward towards revitalizing and improving on the settlements, in order to reduce such spread in events of subsequent outbreaks. From the analysis above, it is convincing that most of the settlements selected are slums, shanty/ghetto, face me I face you etc. They are highly congested with too many people living in them, many of whom are not aware of the activities going on elsewhere.

These people do not know what social distancing is all about, the use of nose mask is alien to them, regular washing of hands seems like punishment to them since there is no running water in their settlements, while alcohol basedsanitizers to them, is meant for hospitals. The pattern of settlements in these areas have made the people not familiar with realities of the modern day life, making them vulnerable and victims of circumstances. To this end, it would be necessary for the government to introduce redevelopment, spot clearance, and rehabilitation strategies in some of these settlements using incremental approach within a stipulated period. This would help the inhabitants and their settlements improved compared with cities/towns elsewhere and as such reduce the spread of subsequent outbreak of diseases.

\section{ACKNOWLEDGMENT}

Finally, we are grateful to all authors whose materials and reports are used in bringing out this paper, NCDC, WHO and others in the Bibliography. Our families, for the show of love by giving us time to be away from them during this period and our colleagues and friends, we say bravo to you all.

\section{REFERENCES}

[1] Adediran, A. (2010). Re: The Focus of Planning Practice Nigeria. Ibadan: Macmillan Publishers.

[2] Agbola, T. (2004). Readings in Urban and Regional Planning. Ibadan: Macmillan Nigeria Publishers Ltd.

[3] Ango, M. S. (2019). Physical Planning Administration and Challenges of Urban Development in Nigeria: An Expert Paper Presented. At the 2019 Town Planners Registration Council of Nigeria (TOPREC) Induction Ceremony (pp. 9-21). Abuja: TOPREC.

[4] Avis, W. R. (2019). Urban Expansion in Nigeria: Knowledge, Evidence, \& Learning for Development. Birmingham: University of Birmingham, UK .

[5] Nigerian Centre for Disease Control (NCDC) (2020). Baseline Report and Interim Management of Covid-19 in Nigeria.

[6] Obongha, U. E., Ukam, L. E., \& Upuji, J. K. (2020). The Impact of Forest Loss on Biodiversity Systems of Cross River State, Nigeria. International Journal of Scientific and Engineering Research, Vol 11: (5), 706-722.

[7] Oloyiwole, A. M., Ajala, O. A., \& Sargodipe, J. A. (2014). Physical Growth Pattern of Settlements in a Traditional Region, Southwest Nigeria. International Journal of Geosciences, Vol 4: (1), 1345-1360.

[8] Seto, K. C., Guneralp, B., \& Huntyra, L. R. (2012). Global Forecast of Urban Expansion to 2030 and Direct Impact on Biodiversity and Carbon Pools. Proceedings of National Academy of Sciences, Vol 9: (40), 16083-16088.

[9] World Health Organization (WHO). (2020). Clinincal Management of Covid-19: Interim Guidelines. Geneva: WHO.

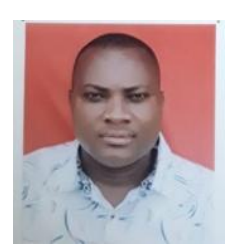

U E. Obongha

A Lecturer in Department of Urban and Regional Planning Cross River University of Technology (CRUTECH), Calabar, Nigeria. He is a research scholar currently working on Analysis of Incompatible Land Uses in Calabar Metropolis, Nigeria. He is also a Consultant and Director of Ezerach \& Sons Ltd. Member of the Nigerian Institute of Town Planners (NITP) and Registered Town Planner (RTP)

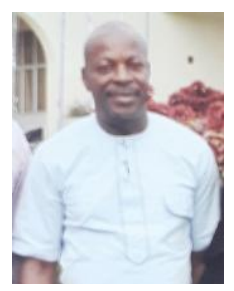

Dr. L. E. Ukam

$\mathrm{He}$ is a Lecturer and former PG and Quality Assurance Coordinator, Department of Urban and Regional Planning, Cross River University of Technology, Calabar, Nigeria.

Currently, Head of Department, Urban and Regional Planning, Cross River University of Technology,

Calabar, Nigeria.

Chapter Chairman of the Nigerian Institute of Town Planners (NITP), Cross River State Chapter.

Dr. Ukam is a research fellow with specialty on Tourism Planning and Development. He is a member of the Nigerian Institute of Town Planners (NITP), Registered Town Planner (RTP), Member of the Nigerian Environmental Society (NES), and Member of the Federation of Tourism Association of Nigeria (FTAN) 